\title{
SEQUENCEKOMPETENSI DASAR MATA PELAJARAN BAHASA ARAB KURIKULUM 2013 JENJANG PENDIDIKAN MI, MTS DAN MA
}

\author{
Ela Isnani Munawwaroh \\ IAIN Syaikh Abdurrahman Siddik, Bangka Belitung, Indonesia \\ elaisnani@gmail.com
}

\begin{abstract}
This research is based on the development of 2006 madrasah curriculum into 2013 curriculum. One of the reason to develove a curriculum is to improve the previous curriculum. So, based on this statement, 2013 curriculum is should be better than previous curriculum. Therefore, I do this research. This research is a qualitative research using library research. The method to collect data is used documents and literarture sources. And to analyze the data is used content analysis with descriptive analysis method. The theory that used in this research is what Jack C. Richards initiated. He said that to determine the sequnces of objectives and subject matter is based on the following criteria, they are: simple to complex, chronology, need, prerequisite learning, whole to part or part to whole, dan spiral sequencing. I also used the theories that intiated by Mahmud Kamil An-Naqoh about the standards of language's competences on 4 arabic language's competences. The results of this research are the basic comptences of Arabic language's lesson in 2013 curriculum is describe on 3 aspects, they are attitude, knowledge and skill. And the sequence of basic competences in arabic language's lesson from first class of MI until twelfth class of MA is presented from simple into complex. However, a number of lack were found, they are decreasing of the competences in listening skill at Madrasah Aliyah's level and it didn't present loudly reading activity in the first levels. And for the themes of arabic language and grammar is used spiral sequencing, which there are some repeating of some themes at the next classes. The repeating is for confirmation and deepening of the previous lesson. However, there were same previous materials is presented at the next class.
\end{abstract}

Keywords: Sequence, Basic competence 


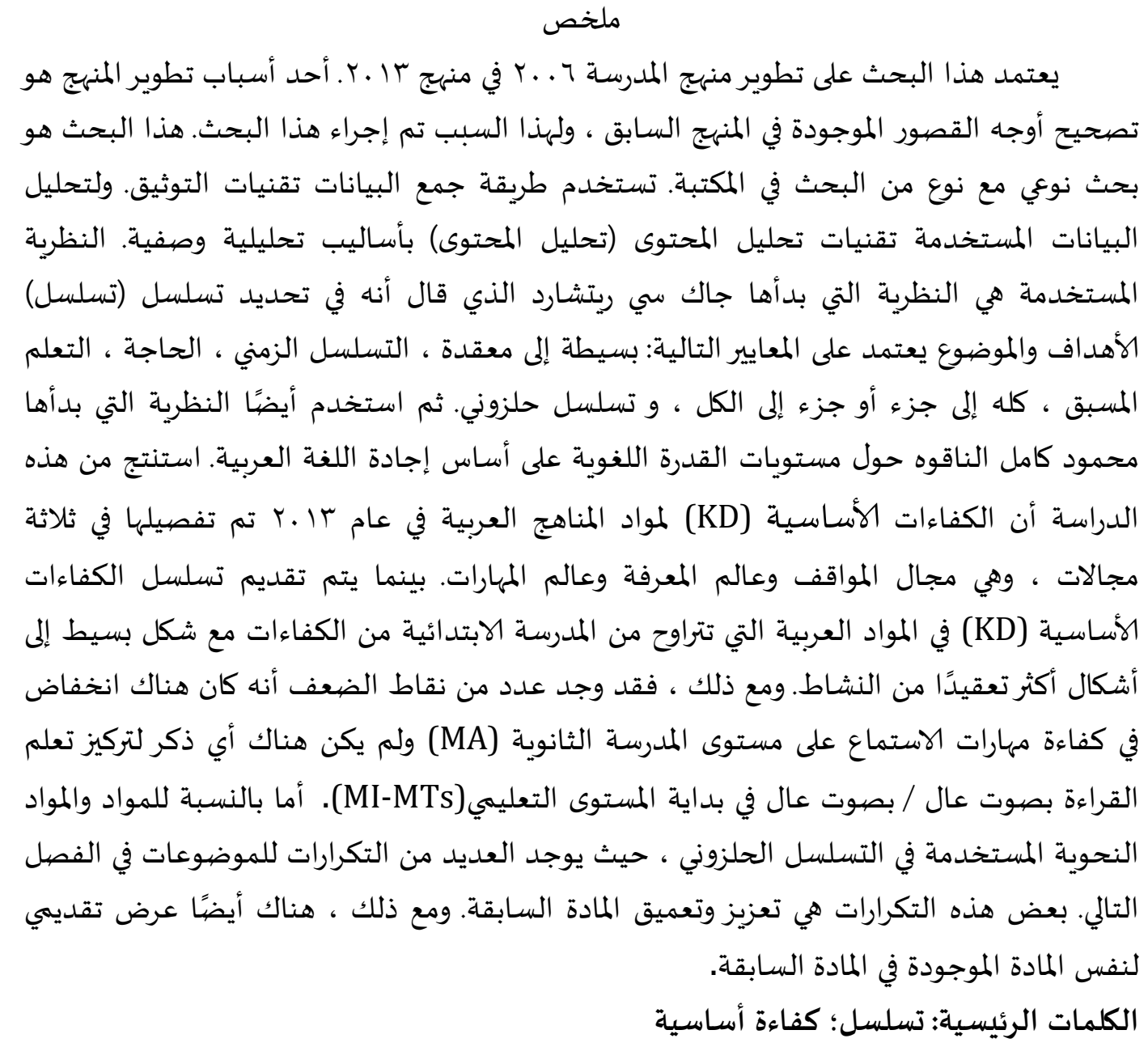

\section{Abstrak}

Penelitian ini didasarkan pada adanya pengembangan kurikulum madrasah tahun 2006 menjadi kurikulum 2013. Salah satu alasan adanya pengembangan suatu kurikulum adalah untuk memperbaiki kekurangan yang ada dalam kurikulum sebelumnya, sehingga dengan alasan tersebut dilakukan penelitian ini. Penelitian ini merupakan penelitian kualitatif dengan jenis penelitian kepustakaan (library research). Metode pengumpulan data menggunakan teknik dokumentasi. Dan untuk menganalisis data digunakan teknik analisis isi (content analysis) dengan metode deskriptif analitis. Teori yang digunakan adalah teori yang digagas oleh Jack C. Richard yang mengatakan bahwa dalam menentukan urutan (sequence) tujuan dan materi pelajaran didasarkan pada kriteria berikut: simple to complex, chronology, need, prerequisite learning, whole to part or part to whole, dan spiral sequencing. Selanjutnya digunakan juga teori yang digagas oleh Mahmud Kamil An-Naqoh tentang tingkatan-tingkatan kemampuan berbahasa berdasarkan empat kemahiran berbahasa Arab. Dari penelitian tersebut disimpulkan bahwa Kompetensi Dasar (KD) mata pelajaran bahasa Arab kurikulum 2013 terjabarkan dalam tiga ranah, yaitu ranah sikap, ranah pengetahuan dan ranah keterampilan. Sedangkan sequence 
Kompetensi Dasar (KD) dalam mata pelajaran bahasa Arab mulai dari kelas I MI hingga kelas XII MI disajikan mulai dari kompetensi dengan bentuk yang sederhana menuju bentuk kegiatan yang lebih kompleks. Namun demikian, beberapa kelemahan yang ditemukan adalah terdapat penurunan kompetensi kemahiran menyimak pada jenjang Madrasah Aliyah (MA) dan tidak dicantumkan fokus pembelajaran membaca dengan suara keras/nyaring pada awal-awal jenjang pendidikan (MI-MTs). Sedangkan untuk materi pelajaran dan materi tata bahasa digunakan spiral sequencing, dimana terdapat beberapa pengulangan tema pada kelas selanjutnya. Beberapa pengulangan tersebut merupakan penguatan dan pendalaman materi sebelumnya. Namun, terdapat pula penyajian materi yang sama dengan materi pada kelas sebelumnya.

\section{Kata Kunci: Sequence, Kompetensi Dasar}

\section{PENDAHULUAN}

Kurikulum madrasah di Indonesia sendiri disusun pertama kali pada tahun 1975 dengan muatan pelajaran agama sebanyak 30\%. Sejak itu, kurikulum madrasah mengalami perubahan mulai dari kurikulum tahun 1975, 1984, 1994, 2004, 2006 hingga kurikulum 2013 yang digunakan sekarang ini. Pada dasarnya, pengembangan suatu kurikulum bertujuan untuk memperbaiki kualitas kurikulum sebelumnya, sehingga tujuan pembelajaran yang diharapkan bisa tercapai dengan maksimal.

Dalam pengembangan kurikulum sendiri terdapat berbagai asas dan prinsip yang harus diperhatikan. Salah satu prinsip yang harus diperhatikan adalah terkait dengan sequence (urutan) suatu materi disajikan. Contohnya, pembelajaran tentang menulis huruf-huruf hijaiyah harus didahulukan sebelum mengajarkan mereka menulis kata atau kalimat dalam bahasa Arab dikarenakan kemampuan menulis huruf-huruf hijaiyah menjadi prasyarat yang harus dikuasai oleh peserta didik sebelum mereka diajarkan menulis kata atau kalimat dalam bahasa Arab.

Dalam kurikulum sebelumnya, yakni KTSP, masalah sequence mengalami kelemahan dan kekurangan. Kelemahan dan kekurangan tersebut bisa dilihat pada penelitian Farida Lutfiani Azizah yang membahas tentang scope, balance dan desain kurikulum 2008 pada mata pelajaran bahasa Arab yang menunjukkan hasil bahwa dalam penyusunan kurikulum 2008 mata pelajaran bahasa Arab tersebut masih tidak memperhatikan kriteria pemilihan bahan pelajaran. Keseimbangan antar komponen dalam kurikulum bahasa Arab tersebut khususnya pada komponen tujuan juga masih belum terlihat (Azizah, 2013). Penelitian lain dilakukan oleh Ismatul Maula menyebutkan bahwa isi kurikulum 2008 mata pelajaran bahasa Arab tersebut juga tidak memperhatikan adanya penerapan aspek urutan 
(sequence) bahan mata pelajaran bahasa Arab tersebut (Maula, 2012). Berdasarkan kedua penelitian tersebut menunjukan bahwa masih adanya kekurangan dalam penyusunan kurikulum bahasa Arab, baik pada tujuan pembelajaran maupun bahan pelajaran bahasa Arab.

Melihat permasalahan di atas, dengan adanya perubahan kurikulum Tingkat Satuan Pendidikan (KTSP) menjadi kurikulum 2013 seharusnya menunjukkan fakta bahwa kurikulum 2013 jauh lebih baik dari kurikulum sebelumnya, karena ia merupakan pengembangan dan perbaikan dari kurikulum sebelumnya. Namun, saat dilakukan penelitian awal (preliminary research) terhadap kurikulum 2013 khususnya mata pelajaran bahasa Arab, masih ditemukan adanya kekurangan dan kelemahan dalam hal penyusunan Kompetensi Dasar (KD). Sebagai contoh, dalam kurikulum tersebut ditemukan KD yang berisi tentang pengenalan huruf-huruf hijaiyah terdapat pada butir KD kelas IV MI. Padahal pembelajaran bahasa Arab sudah diajarkan sejak kelas I MI dengan KD berupa pengenalan kosakata baik secara lisan maupun tulisan.

Selanjutnya, Hilda Toba menyebutkan bahwa bukan hanya urutan bahan pelajaran yang diperhatikan, namun juga proses belajar (Nasution, 2006). Kedua hal ini -bahan pelajaran dan proses belajar- dalam kurikulum bisa kita lihat pada kompetensi pembelajaran yang disusun. Oleh sebab itu, fokus penelitian disini adalah pada bahan pelajaran dan proses belajar yang tertuang dalam Kompetensi Dasar (KD) mata pelajaran bahasa Arab dalam kurikulum 2013. Sedangkan objek penelitian disini adalah seluruh Kompetensi Dasar (KD) pelajaran bahasa Arab dalam kurikulum 2013 jenjang pendidikan Madrasah Ibtidaiyah (MI), Madrasah Tsanawiyah (MTs) dan Madrasah Aliyah (MA). Pemilihan objek tersebut dilakukan agar bisa memperoleh hasil penelitian yang lebih komprehensif.

Adapun fokus penelitian ini adalah untuk mengetahui gambaran Kompetensi Dasar (KD) mata pelajaran bahasa Arab dakam kurikulum 2013 serta sequencedari Kompetensi Dasar (KD) tersebut mulai dari jenjang pendidikan MI, MTs, hingga MA. Alasan peneliti memilih penelitian ini adalah untuk memberikan masukan kepada pihak-pihak terkait tentang Kompetensi Dasar (KD) mata pelajaran bahasa Arab agar bisa dikembangkan lebih baik lagi. 


\section{LANDASAN TEORI}

\section{Sequence dalam Pengembangan Kurikulum Bahasa}

Sequence berarti urutan (order) pengalaman-pengalaman pendidikan yang dimajukan bersama siswa. Sequence mempersoalkan "when" dalam perencanaan kurikulum (Sutopo, 1986).

Sequence merupakan salah satu prinsip dalam pengembangan kurikulum. Hal tersebut juga berlaku dalam pengembangan kurikulum bahasa. Menurut Hilda Toba, ada dua hal yang perlu diperhatikan dalam menentukan sequence terkait dengan pengembangan kurikulum, yaitu: urutan bahan pelajaran dan juga proses belajar. Urutan proses belajar antara lain mengenai langkah-langkah untuk mengembangkan konsepkonsep, sikap dan kesanggupan berfikir (Nasution, 2006).

Jack C. Richards menyebutkan bahwa penentuan urutan tersebut didasarkan kriteria-kriteria berikut, yaitu: "simple to complex(dari yang sederhana ke yang kompleks), chronology (urutan waktu), need (kebutuhan), prerequisite learning (pelajaran prasyarat), whole to part or part to whole (keseluruhan ke bagian atau bagian ke keseluruhan), spiral sequenceing (urutan spiral) (Richards, 2001).

\section{a. Simple to Complex}

Salah satu cara yang paling umum untuk menentukan sequence dalam pengembangan kurikulum bahasa adalah berdasarkan tingkat kesulitannya atau dengan kata lain easy to difficult. Berdasarkan kriteria ini, tujuan dan materi yang sederhana diajarkan lebih dulu daripada materi yang sulit. Contoh, peserta didik diajarkan cara menulis huruf-huruf hijaiyah satu per satu sebelum diajarkan menulis huruf-huruf tersebut dalam bentuk kata.

b. Chronology

Sequence proses belajar dan bahan pelajaran bisa juga ditentukan berdasarkan chronology (urutan waktu) kapan ia terjadi atau ada dalam dunia nyata. Contoh, dalam pembelajaran kemahiran berbahasa, maka urutan pembelajarannya secara umum dimulai dari kemahiran menyimak, berbicara, membaca dan kumudian menulis.

c. Need

Maksud dari kriteria ini adalah kapan suatu hasil pembelajaran dibutuhkan oleh peserta didik untuk digunakan dalam dunia nyata. Misalnya, dalam pembelajaran kemahiran menyimak, urutan kompetensi yang diperlukan peserta didik adalah sebagai beikut:

1) Mengenali huruf-huruf hijaiyah 
2) Mengenali bacaan harokat panjang dan pendek

3) Mengenali bacaan yang bertasydid dan bertanwin, dst.

Mengenali huruf-huruf hijaiyah diperlukan terlebih dahulu dikarenakan untuk mengenali bacaan yang berharokat panjang atau pendek, serta bacaan yang bertasydid dan bertanwin maka peserta didik perlu mengetahui terlebih dahulu huruf-huruf hijaiyah.

\section{d. Prerequisite learning}

Urutan proses pembelajaran dan bahan pelajaran juga bisa didasarkan pada tujuan atau bahan yang menjadi prasyarat bagi tujuan dan bahan pelajaran selanjutnya. Contoh, diperlukan pengajaran untuk mengajarkan tata bahasa tertentu sebelum mengajarkan siswa dalam kemahiran menulis (mengarang).

e. Whole to part or part to whole

Pada awal suatu mata pelajaran bisa saja diungkapkan tujuan pembelajaran yang bersifat umum sebelum menentukan tujuan yang lebih khusus. Namun untuk mencapai tujuan yang umum, maka bisa dilakukan dengan pembelajaran dari bagian (part) menuju ke keseluruhan (whole).

f. Spiral Sequencing

Kriteria ini menuntut akan adanya pengulangan materi-materi sebelumnya dengan cara mengolah materi-materi yang ada dalam konteks yang lebih luas dan dalam dari sebelumnya atau dengan kata lain materi yang diajarkan merupakan pengembangan dari materi sebelumnya (development). Hal ini akan berguna untuk mengingat kembali materi-materi yang telah diajarkan.

\section{Sequence dalam Pembelajaran Bahasa Arab}

Pembelajaran bahasa Arab meliputi pembelajaran terhadap empat kemahiran bahasa yang meliputi kemahiran menyimak, kemahiran berbicara, kemahiran membaca dan kemahiran menulis serta dua komponen bahasa yang meliputi kosakata dan tata bahasa.Lebih lanjut An-Naqoh berpendapat bahwa kemahiran menyimak dan kemahiran berbicara lebih dahulu diajarkan daripada kemahiran membaca dan menulis. Selanjutnya, kemahiran menyimak lebih didahulukan daripada kemahiran berbicara, dan kemahiran membaca lebih didahulukan daripada kemahiran menulis (An-Naqoh, 1985).

Sedangkan dalam setiap kemahiran berbahasa tersebut, maka sequence proses pembelajarannya adalah sebagai berikut: 
a. Kemahiran menyimak, dengan tahapan pembelajaran sebagai berikut:

1) Latihan pengenalan (identifikasi)

2) Latihan mendengarkan dan menirukan

3) Latihan mendengarkan dan memahami.

b. Kemahiran membaca, dengan tahapan pembelajaran sebagai berikut:

1) Latihan pengucapan huruf, kata, frase, dan kalimat bahasa Arab dengan cara menirukan

2) Latihan percakapan (muhadtasah) terbimbing

3) Latihan berbicara dalam konteks yang lebih kompleks, seperti kegiatan percakapan tidak terbimbing, monolog, diskusi atau debat dengan menggunakan bahasa Arab.

c. Kemahiran membaca, dengan tahapan pembelajaran sebagai berikut:

1) Latihan membaca huruf dan kata dalam bahasa Arab lengkap dengan karakteristik khusus bahasa Arab seperti harokat, tanwin, dan tasydid

2) Latihan membaca kata, frase, dan kalimat bahasa Arab

3) Latihan memahami teks melalui kegiatan membaca, baik membaca dengan suara keras ataupun membaca dalam hati.

d. Kemahiran menulis, dengan tahapan pembelajaran sebagai berikut:

1) Mencontoh

2) Imla'

3) Rekombinasi (menggabungkan kata-kata atau kalimat-kalimat yang belum tersusun menjadi kalimat yang benar dan bermakna) dan transformasi (mengubah bentuk kalimat ke bentuk kalimat lain dengan tetap memiliki makna yang sama).

\section{METODE PENELITIAN}

Penelitian ini merupakan penelitian kepustakaan (library research) yaitu jenis penelitian yang dilakukan oleh seorang peneliti dengan cara mengumpulkan data yang bersumber dari buku, jurnal, kitab, artikel, dan tulisan-tulisan tertentu(Pohan, 2007). Adapun pendekatan yang digunakan adalah pendekatan kualitatif.

Adapun sumber data primer penelitian ini menggunakan Surat Keputusan Direktur Jenderal Pendidikan Islam No. 2676 tahun 2013 yang berisi tentang kurikulum 2013 mata pelajaran pendidikan Agama Islam dan bahasa Arab di Madrasah. Sedangkan beberapa sumber sekunder yang digunakan adalah Lampiran Peraturan Menteri Agama, perangkat pembelajaran seprti Buku Ajar, RPP, dan Silabus, Buku Curriculum Development in Language Teaching yang ditulis oleh Jack C. Richards, dan 
buku Ta'limul Lughah al-'Arabiyah yang ditulis oleh Mahmud Kamil AnNaqoh.

Teknik pengumpulan data menggunakan teknik dokumentasi. Sedangkan untuk menganalisis data digunakan metode deskriptif analitis yang dimulai dengan pengumpulan data, dilanjutkan dengan penyusunan dan pengklasifikasian data. Selanjutnya dilakukan perbandingan data, interpretasi dan penarikan kesimpulan.

\section{HASIL PENELITIAN}

Sequence Kompetensi Dasar (KD) mata pelajaran bahasa Arab kelas I MI hinggan kelas XII MA berdasarkan kemahiran berbahasa Arab dan Komponen bahasa bisa dijabarkan sebagai berikut:

\section{Berdasarkan kemahiran berbahasa Arab}

a. Kemahiran Menyimak

Kompetensi Dasar (KD) yang terkait dengan kemahiran menyimak pada mata pelajaran bahasa Arab dalam Kurikulum 2013 terdapat dalam ranah pengetahuan sebagai berikut:

1) Mengenal bunyi mufrodat dengan topoik tertentu diajarkan pada kelas I MI, II MI, dan III MI

2) Mengenal ujaran mufrodat diajarkan pada kelas III MI

3) Mengidentifikasi bunyi huruf, kata, frase, dan kalimat dengan topik tertentu diajarkan pada kelas IV MI, V MI, dan VI MI

4) Mengidentifikasi bunyi huruf, frase dan kalimat dengan topik tertentu, diajarkan pada kelas VII MTs, VIII MTs, IX MTs, X MA, XI MA dan XII MA

5) Memahami lafal bunyi huruf, kata, frase, dan kalimat bahasa Arab sesuai dengan topik tertentu diajarkan pada kelas VII MTs, VIII MTs dan IX MTs

Pada kemahiran menyimak terdiri dari lima bentuk kegiatan. Pada butir nomor satu dan dua memiliki bentuk kegiatan yang sama, dimana peserta didik melakukan kegiatan mengenal bunyi/ujaran mufrodat. Sedangkan pada butir ketiga, bentuk kegiatan sama dengan butir nomor satu dan dua, namun sudah naik pada level kegiatan mengenal atau mengidentifikasi bunyi huruf, kata, frase dan kalimat dengan topik tertentu. Pada butir keempat, bentuk kegiatan menyimak sama dengan butir ketiga, hanya saja kompetensi yang diharapkan meningkat dalam hal materi yang diajarkan, yaitu memahami lafal bunyi kata, frase dan kalimat bahasa Arab sesuai 
dengan topik tertentu. Sedangkan pada butir kelima, kompetensi meningkat pada kemampuan peserta didik dalam memahami lafal bunyi huruf, kata, frase dan kalimat yang diajarkan.

Dalam hal ini, sequence pembelajaran kemahiran menyimak dimulai dari pembelajaran mufrodat hingga kelas III MI. Pada kelas IV MI hingga kelas VI MI, kemahiran menyimak masih dalam bentuk mengidentifikasi bunyi.Namun, bunyi yang diajarkan terkait dengan bunyi huruf, kata, frase dan kalimat sederhana terkait dengan topik.

Pada kelas VII MTs hingga kelas IX MTs, kegiatan pembelajaran kemahiran menyimak mengalami peningkatan dalam hal materi dimana pada jenjang pendidikan MI peserta didik disajikan materi mulai dari pengenalan bunyi huruf.Namun pada jenjang Madrasah Tsanawiyah identifikasi bunyi dimulai dari bunyi kata yang tingkatannya lebih kompleks dari pengenalan bunyi huruf.

Selain itu, pada tingkat MTs ini, peningkatan pada kemahiran menyimak terdapat pada kegiatan memahami lafal bunyi huruf kata frasa dan kalimat bahasa Arab yang diperdengarkan sesuai dengan topik tertentu. Namun dalam hal ini, kita menemukan adanya inkonsistensi antara kegiatan menyimak sebelumnya pada jenjang pendidikan dan kelas yang sama, dimana pada pernyataannya ditulis kegiatan mengidentifikasi bunyi kata frase dan kalimat. Sedangkan pada kegiatan memahami lafal dimulai dari memahami lafal bunyi huruf, kata frase dan kalimat bahasa Arab.Meskipun hal ini sebenarnya tidak memiliki pengaruh yang begitu besar namun hal ini menunjukkan minimnya ketelitian pengembang kurikulum dalam menyusun kurikulum tersebut.

Pada jenjang selanjutnya yaitu jenjang pendidikan Madrasah Aliyah bentuk kegiatan pembelajaran kemahiran menyimak masih sama dengan kegiatan pada jenjang pendidikan sebelumnya. Tidak ada peningkatan bentuk kegiatan yang diberikan, yaitu masih berada pada kegiatan mengidentifikasi bunyi kata, frase dan kalimat bahasa Arab.Dan hal yang kurang diperhatikan lagi di sini adalah kemampuan memahami lafal bunyi kata, frase dan kalimat bahasa Arab yang tidak dicantumkan kembali, padahal di jenjang pendidikan Madrasah Tsanawiyah sudah dicantumkan.hal ini menunjukkan adanya penurunan dalam kompetensi yang diharapkan.

Dengan demikian, dapat disimpulkan bahwa sequence Kompetensi Dasar (KD) terkait dengan kemahiran menyimak dimulai dari bentuk kemahiran yang sederhana menuju ke kemahiran yang lebih 
kompleks dari kelas 1 MI hingga kelas IX MTs. Namun kelemahannya disini terdapat pada penyajian Kompetensi Dasar (KD) pada jenjang MA, dikarenakan bentuk kemahiran menyimak yang disajikan menurun dimana pada jenjang MTs sudah difokuskan pada bentuk kemahiran menyimak disertai dengan pemahaman peserta didik terhadap apa yang didengarkan. Namun pada jenjang pendidikan MA bentuk kemahiran menyimak tersebut tidak dicantumkan kembali.

b. Kemahiran Berbicara

Kompetensi Dasar (KD) yang terkait dengan kemahiran berbicara pada mata pelajaran bahasa Arab dalam Kurikulum 2013 terdapat dalam ranah pengetahuan sebagai berikut:

1) Mengenal bunyi mufradat dengan topik tertentu dengan lisan diajarkan pada kelas IMI, IIMI, dan III MI.

2) Mengidentifikasi bunyi huruf, kata, frase, dan kalimat dengan topik tertentu secara lisan, diajarkan pada kelas IV MI, V MI dan VIMI.

3) Mengidentifikasi bunyi huruf, kata, frase, dan kalimat dengan topik tertentu secara lisan, diajarkan pada kelas VIIMTs,VIIIMTs, IXMTs,X MA, XIMA dan XII MA.

4) Melafalkan kata, frase, dan kalimat bahasa Arab berkaitan dengan topik tertentu diajarkan pada kelas X MA, XIMA dan XII MA.

5) Mengungkapkan makna atau gagasan dari ujaran kata, frasa, dan kalimat bahasa Arab yang diperoleh dari kegiatan membaca sesuai dengan topik tertentu dalam bentuk lisan, diajarkan pada kelas $\mathrm{X}$ MA, XIMA dan XII MA.

6) Menirukan bunyi mufrodat terkait topik diajarkan pada kelas I MI, IIMI, dan III MI.

7) Melafalkan ujaran kata (mufrodat) diajarkan pada kelas IIMI dan III MI.

8) Mempraktikkan bunyi huruf, kata, frase, dan kalimat bahasa Arab terkait topik diajarkan pada kelas IV MI,V MI dan VI MI

9) Memperagakan kata, frase, dan kalimat sederhana terkait topik, diajarkan pada kelas IV MI, V MI dan VI MI.

10)Mendemonstrasikan kata, frase, dan kalimat sederhana secara lisan diajarkan pada kelas IV MI

11)Mendemonstrasikan kata, frase, dan kalimat sederhana secara lisan terkait dengan topik tertentu dalam berbagai struktur bahasa sederhana yang tepat diajarkan pada kelas V MI dan VI MI. 
12)Mendemonstrasikan ungkapan sederhana terkait topik tertentu dengan memperhatikan struktur teks dan unsur kebahasaan yang benar dan sesuai konteks diajarkan pada kelas VII MTs,VIII MTs dan IX MTs

13)Menunjukkan contoh ungkapan sederhana untuk menyatakan, menanyakan dan merespon tentang topik tertentu dengan memperhatikan struktur teks dan unsur kebahasaan yang benar dan sesuai konteks diajarkan pada kelas VII MTs,VIII MTs dan IX MTs.

14)Mempresentasikan berbagai informasi lisan sederhana terkait dengan topik tertentu, diajarkan pada kelas VII MTs,VIII MTs dan IX MTs.

15)Melakukan dialog sederhana sesuai konteks dengan tepat dan lancar terkait topik tertentu dengan memperhatikan unsur kebahasaan struktur teks dan unsur budaya secara benar dan sesuai konteks diajarkan pada kelas XMA,XI MA dan XII MA

16)Menyampaikan berbagai informasi desain sederhana tentang topik tertentu dengan memperhatikan unsur kebahasaan, struktur teks dan unsur budaya secara benar dan sesuai konteks, diajarkan pada kelas XMA,XI MA dan XII MA

17)Memproduksi teks lisan sederhana untuk mengungkapkan cara memberitahu dan menanyakan fakta, perasaan dan sikap terkait topik tertentu dengan memperhatikan unsur kebahasaan, struktur teks dan unsur budaya secara benar dan sesuai dengan konteks, diajarkan pada kelas XMA,XI MA dan XII MA

18)Menyusun teks lisan sederhana untuk mengungkapkan informasi terkait topik tertentu sesuai dengan unsur kebahasaan dan budaya, diajarkan pada kelas XMA,XI MA dan XII MA.

Kemahiran ini menduduki posisi yang paling dominan dalam pembelajaran bahasa Arab sebagaimana dipahami dari kompetensi dasar (KD) mata pelajaran bahasa Arab dalam kurikulum 2013. Kemahiran ini tercantum dalam kompetensi dasar atau KD untuk ranah pengetahuan dan ranah keterampilan.

Adapun sequence dalam kemahiran berbicara tersebut adalah sebagai berikut:

Kemahiran berbicara dimulai dari bentuk kegiatan mengenal bunyi mufradat secara lisan sebagai kelanjutan kegiatan menyimak. Kegiatan ini diajarkan dari kelas I MI hingga kelas III MI. Adapun materi yang diajarkan berkaitan dengan mufrodat atau kosakata. Hal 
ini dikarenakan kegiatan berbicara merupakan respon dari pembelajaran kemahiran menyimak.

Pada kelas I MI terkait dengan kemahiran berbicara juga terdapat kegiatan berupa menirukan bunyi mufrodat terkait dengan topik. Hal ini memiliki kesamaan dengan bentuk kegiatan di atas yang berupa mengenal bunyi mufradat secara lisan. Pada kelas II MI dan III MI juga ditemukan bentuk kegiatan yang sama yaitu berupa melaporkan ujaran kata atau mufrodat terkait dengan topik. Banyaknya bentuk kegiatan yang sama tersebut menegaskan bahwa peserta didik memang dituntut untuk bisa menguasai pelajaran yang diajarkan dalam kegiatan berbicara, karena pembelajaran bahasa memang harus selalu dipraktekkan.

Sedangkan pada kelas IV MI, V MI dan VI MI, pembelajaran kemahiran berbicara berupa kegiatan mengidentifikasi bunyi huruf kata atau frase dan kalimat secara lisan. Dalam hal ini ditemukan bahwa pembelajaran bahasa ikut memfokuskan perhatian pada pengucapan huruf huruf dengan benar setelah peserta didik sebelumnya langsung mempelajari kosakata bahasa Arab.Hal ini dilakukan untuk mempertajam kemampuan pelafalan lafal bahasa Arab peserta didik. Bentuk kegiatan tersebut sama pada kelas IV MI, V MI dan VI MI, yaitu kegiatan mempraktikkan bunyi huruf, kata, frase, dan kalimat bahasa Arab dan kegiatan memperagakan kata, frase dan kalimat sederhana. Ketiga poin dari kemahiran berbicara pada kelas IV MI, V MI dan VI MI memiliki kesamaan.

Selain itu juga terdapat bentuk kegiatan yang sama pada kelas IV MI dengan di atas yaitu bentuk kegiatan mendemonstrasikan kata frase dan kalimat sederhana secara lisan. Begitu juga halnya dengan kelas V MI dan VI MI. Yang membedakannya adalah pada materi kelas V MI dan VI MI sudah memperhatikan penggunaan struktur bahasa dengan tepat.

Jenjang pendidikan selanjutnya yaitu Madrasah Tsanawiyah.Kemahiran berbicara yang diajarkan pada kelas VIIMTs, VIII MTs dan IX MTs yaitu berupa pengidentifikasian bunyi kata, frase, dan kalimat bahasa Arab secara lisan. Kemudian dilanjutkan dengan mendemonstrasikan ungkapan sederhana terkait dengan topik tertentu,menunjukkan contoh ungkapan sederhana untuk menyatakan, menanyakan, dan merespon serta mempresentasikan berbagai informasi secara lisan tentang topik tertentu. Kegiatan ini 
sudah turut memperhatikan struktur teks dan unsur kebahasaan yang benar.

Selanjutnya pada jenjang pendidikan Madrasah Aliyah (MA) kelas XMA hingga kelas XII MA masih menekankan kegiatan pengidentifikasian bunyi kata frase dan kalimat bahasa Arab secara lisan sebagai kegiatan utama. Kegiatan ini mirip dengan kegiatan pada butir Kompetensi Dasar (KD) yang lainnya yaitu melafalkan kata, frase dan kalimat berkaitan dengan topik tertentu. Kegiatan tersebut meningkat kepada kegiatan mengungkapkan makna suatu teks dari kegiatan membaca secara lisan. Pada tingkat yang lebih kompleks, kegiatan pembelajaran berbicara ditingkatkan kepada kegiatan percakapan dan menyampaikan berbagai informasi lisan sederhana terkait topik tertentu. Selain itu, kegiatan pembelajaran kemahiran berbicara juga menekankan kegiatan memproduksi teks lisan sederhana untuk mengungkapkan cara memberitahu dan menanyakan fakta, perasaan dan sikap terkait topik tertentu serta menyusun teks lisan sederhana. Kegiatan berbicara pada jenjang Madrasah Aliyah (MA) ini sudah ikut memperhatikan unsur kebahasaan, struktur teks dan unsur budaya dengan benar.

Berdasarkan pemaparan sequencedi atas dapat kita simpulkan bahwa kemahiran berbicara memiliki posisi yang dominan dalam pembelajaran. Hal ini menunjukkan adanya usaha penyusun kurikulum untuk memperbanyak praktek dalam pembelajaran bahasa. Selain itu, bentuk kemahiran berbicara yang disajikan dimulai dari bentuk yang paling sederhana yakni pelafalan kosakata menuju ke yang lebih kompleks dimana peserta didik harus memperhatikan unsur kebahasaan dalam berbicara menyampaikan ide.

c. Kemahiran Membaca

Kompetensi Dasar (KD) yang terkait dengan kemahiran membaca pada mata pelajaran bahasa Arab dalam Kurikulum 2013 terdapat dalam ranah pengetahuan sebagai berikut:

1) Memahami kata, frase, dan kalimat sederhana secara lisan, diajarkan pada kelas IV MI, V MI dan VI MI

2) Menemukan makna atau gagasan dari ujaran kata, frase, dan kalimat bahasa Arab berkaitan dengan topik tertentu diajarkan pada kelas VII MTs, VIII MTs dan IX MTs, X MA, XI MA dan XII MA.

3) Melafalkan kata, frase, dan kalimat bahasa Arab berkaitan dengan topik tertentu, diajarkan pada kelas X MA, XI MA dan XII MA. 
4) Membuat analisis sederhana dari sebuah teks berkaitan dengan unsur budaya, unsur kebahasaan dan struktur teks, diajarkan pada kelas X MA, XI MA dan XII MA.

Pembelajaran pada kemahiran membaca disajikan pada kelas IV MI dengan fokus pembelajaran terletak pada pemahaman terhadap kata, frase, dan kalimat bahasa Arab. Kegiatan ini juga berlaku pada kelas V MI hingga kelas XI MA. Peningkatan keterampilan terdapat pada kelas VII MTs hingga kelas XII MA dimana peserta didik dituntut untuk bisa menemukan makna atau gagasan dari apa yang mereka baca. Selanjutnya fokus pada kemahiran membaca di ditekankan pada kegiatan melafalkan kata, frase, dan kalimat bahasa Arab pada kelas XMA hingga kelas XII MA. Dan pada jenjang MA ini juga diajarkan kemampuan peserta didik dalam menganalisis apa yang ia baca terkait dengan unsur budaya, unsur kebahasaan dan struktur teks.

Dengan demikian dapat disimpulkan bahwa sequence Kompetensi Dasar (KD) pada kemahiran membaca ini bermula dari bentuk pembelajaran yang sederhana menuju yang lebih kompleks. Namun kekurangan yang ditemukan terkait dengan kemahiran membaca ini adalah tidak adanya kegiatan pembelajaran membaca pada kelaskelas awal tersebut dalam bentuk membaca keras.Hal ini sangat diperlukan untuk menunjang kemampuan peserta didik pada tingkat selanjutnya. Kekurangan inilah menurut penulis yang kemudian menjadi penyebab minimnya kemampuan membaca tulisan Arab kebanyakan peserta didik yang baru ditemukan ketika mereka berada pada jenjang pendidikan Madrasah Tsanawiyah (MTs) ataupun Madrasah Aliyah (MA) sehingga pada jenjang ini guru masih dibebani tugas untuk mengajarkan peserta didik membaca tulisan Arab. Hal ini kemudian menyebabkan kurangnya perhatian pada kemahiran kemahiran yang lainnya.

d. Kemahiran Menulis

Kompetensi Dasar (KD) yang terkait dengan kemahiran menulis pada mata pelajaran bahasa Arab dalam Kurikulum 2013 terdapat dalam ranah pengetahuan sebagai berikut:

1) Mengenal bunyi mufrodat dengan topik tertentu dengan tulisan diajarkan pada kelas I MI, II MI dan III MI

2) Mengidentifikasi bunyi huruf, kata, frase, dan kalimat dengan topik tertentu secara tulisan, diajarkan pada kelas IV MI, V MI,VI MI, VII MTs,VIII MTs,IX MTs, X MA, XIMA dan XIIMA. 
3) Memahami kata, frase, dan kalimat sederhana secara tertulis, diajarkan pada kelas IV MI, V MI, danVI MI.

4) Mengungkapkan makna kata atau gagasan dari ujaran kata, frase dan kalimat bahasa Arab yang diperoleh dari kegiatan membaca sesuai dengan topik tertentu dalam bentuk tulisan, diajarkan pada kelas X MA, XI MA dan XII MA.

5) Menyalin mufrodat dan teks sederhana terkait dengan topik diajarkan pada kelas III MI

6) Mengungkapkan informasi secara tertulis tentang topik tertentu dalam berbagai struktur bahasa sederhana secara tepat, diajarkan pada kelas VII MTs, VIII MTs dan IX MTs

7) Menyusun teks sederhana tentang topik tertentu dengan memperhatikan struktur teks dan unsur kebahasaan yang benar sesuai konteks diajarkan pada kelas VII MTs, VIII MTs dan IX MTs

8) Memproduksi teks sederhana dalam bentuk tulisan untuk mengungkapkan cara memberitahu dan menanyakan fakta, perasaan dan sikap terkait topik tertentu dengan memperhatikan unsur kebahasaan, struktur teks dan unsur budaya secara benar dan sesuai dengan konteks, diajarkan pada kelas X MA, XIMA dan XIIMA.

9) Menyusun teks sederhana dalam bentuk tulisan untuk mengungkapkan informasi terkait topik tertentu sesuai dengan unsur kebahasaan dan budaya diajarkan pada kelas X MA, XIMA dan XIIMA.

Lain halnya dengan kemahiran membaca di atas, kemahiran menulis sudah diajarkan sejak kelas I MI dalam bentuk kegiatan pengenalan bunyi mufrodat dengan tulisan. Namun pada kelas I MI ini kemahiran menulis belum menjadi fokus utama pembelajaran.

Pada kelas IV MI, kompetensi yang diajarkan sama dengan kelas III MI. Kompetensi Dasar (KD) kemahiran menulis materi yang diajarkan dimulai dari pengidentifikasian bunyi huruf secara tulisan yang seharusnya sudah dimulai sejak kelas IMI. Sedangkan untuk pembelajaran kemahiran menulis terkait dengan pengidentifikasian bunyi huruf, kata, frase, dan kalimat secara tertulis diajarkan lebih lanjut pada kelas IV MI dan berlanjut hingga kelas XII MA. Namun pada kelas IV MI ini, peningkatan kompetensi peserta didik bisa dilihat pada kegiatan memahami kata, frase, dan kalimat sederhana secara tertulis dari materi yang ia pelajari sebelumnya yakni pada 
kelas IV MI hingga kelas VI MI. Selain itu pada kelas V MI, unsur tata bahasa dalam tulisan peserta didik mulai diperhatikan.

Peningkatan kompetensi kemahiran menulis selanjutnya bisa kita lihat pada kelas VII MTs dimana peserta didik dituntut untuk bisa mengungkapkan informasi dan menyusun teks sederhana tentang topik tertentu dengan memperhatikan struktur teks dan unsur kebahasaan yang tepat. Kegiatan ini diajarkan mulai dari kelas VII MTs hingga kelas IX MTs.

Sedangkan pada tingkat Madrasah Aliyah (MA), peningkatan kemahiran menulis berupa kemampuan memproduksi teks tulisan untuk mengungkapkan cara memberitahu dan menanyakan fakta, perasaan dan sikap terkait topik sesuai dengan unsur budaya dan struktur kebahasaan yang tepat. Kompetensi yang diajarkan juga berupa penyusunan teks sederhana dalam bentuk tulisan untuk mengungkapkan informasi terkait topik tertentu sesuai dengan unsur budaya dan struktur kebahasaan yang tepat.

Berdasarkan hal tersebut, dapat kita simpulkan bahwa sequenceKompetensi Dasar (KD) terkait dengan kemahiran menulis ini diawali dengan bentuk kegiatan yang sederhana menuju ke yang lebih kompleks. Hanya saja pada awal pembelajaran menulis ini tidak ada fokus pada bentuk menulis huruf hijaiyah yang merupakan prasyarat untuk bisa menulis kata yang lebih rumit.Selain itu, materi pembelajaran kemahiran menulis pada kelas selanjutnya berkembang ke materi yang lebih rumit dan luas.

\section{Berdasarkan Komponen Berbahasa}

a. Pembelajaran kosakata dan topik topik pelajaran bahasa Arab

Untuk pembelajaran kosakata, materi disesuaikan dengan topiktopik yang dipelajari pada kelas tersebut sebagaimana yang digambarkan di atas. Pada kelas I MI sampai dengan kelas III MI diajarkan pula beberapa ungkapan komunikatif yang digunakan selama proses pembelajaran. Adapun ungkapan-ungkapan tersebut memiliki sequence yang cukup baik, dimana pengajaran ungkapanungkapan komunikatif tersebut dimulai dengan jumlah yang lebih sedikit. Kemudian pada tiap-tiap kelas terdapat peningkatan atau penambahan dari kelas sebelumnya.

Untuk bahan pelajaran yang diajarkan pada kelas I MI dimulai dari tema-tema yang berkaitan dengan lingkungan siswa di sekolah dan tema-tema yang paling dekat dengan dunia peserta didik seperti 
menghitung dari angka 1 hingga 10. Materi selanjutnya yaitu pada kelas II MI semester II berlanjut kepada tema yang lebih meluas dari sekolah, yaitu tentang alat transportasi dan rambu-rambu lalu lintas. Dan setelah itu materi dikembangkan mengarah kepada tema di lingkungan keluarga hingga kelas $V$ semester 1 . Selain disajikan tematema tersebut, juga diajarkan tema tentang nama-nama penyakit, nama-nama binatang, anggota wudu dan salat lima waktu.

Pada kelas V MI semester II kembali diajarkan tema-tema yang berkaitan dengan lingkungan sekolah dengan menyajikan kembali tema-tema yang sama dengan tema sebelumnya. Pada beberapa tema terdapat pengembangan dari tema sebelumnya, sedangkan pada beberapa tema berupa pengulangan dari tema sebelumnya.Hingga kelas VIIIMTs, tema yang disajikan adalah seputar tema sekolah dan keluarga, dan beberapa tema yang merupakan tema yang telah dipelajari sebelumnya. Untuk menghindari pengulangan tema yang sama, materi tersebut sangat bergantung kepada kemampuan penyusun buku teks pelajaran bahasa Arab.

Tema pada kelas 9 MTS tersebut kemudian berkembang ke arah tema tentang pengetahuan terhadap pengetahuan keislaman seperti peringatan maulid Nabi Muhammad SAW, Nuzulul Quran dan 2 hari raya serta tema tentang kehidupan sosial seperti kehidupan dalam masyarakat, hobi, pekerjaan, fasilitas-fasilitas umum dan lain-lain. Sedangkan pada jenjang Madrasah Aliyah (MA), tema-tema yang disajikan terdapat beberapa pengulangan tema tentang lingkungan keluarga dan lingkungan sekolah. Untuk menghindari pengulangan materi yang sama, maka sangat bergantung pada penyusunan buku teks pelajaran bahasa Arab tersebut. Namun pada kelas XI hingga XIIMA, tema yang disajikan kebanyakan merupakan tema-tema baru yang belum pernah diajarkan sebelumnya.

Dengan demikian, dapat kita simpulkan bahwa sequence dalam penyusunan materi pelajaran bahasa Arab dimulai dari lingkungan terdekat peserta didik, yakni lingkungan sekolah, hal yang paling sering mereka temui seperti menghitung, mengenal warna, dan lainlain, kemudian berkembang kepada lingkungan keluarga dan lingkungan sosial. Namun pada tingkatan kelas tersebut, pembahasan tentang tema sekolah dan tema keluarga disajikan secara bergantian dan diselingi dengan tema-tema lain. Dari tema-tema yang disajikan juga ditemukan adanya beberapa kali pengulangan tema yang sama. Beberapa tema hanya berupa pengulangan, dan beberapa tema 
merupakan perluasan dari tema sebelumnya. Sedangkan untuk tema tentang kehidupan sosial dan kebudayaan Islam banyak dibahas mulai dari kelas IXMTs hingga kelas XMA.

b. Pembelajaran tata bahasa

Materi tata bahasa diajarkan mulai dari kelas IV MI. Tata bahasa yang diajarkan tersebut termasuk pada bentuk spiralsequenceing, dimana terdapat beberapa pengulangan materi materi sebelumnya namun dalam bentuk yang lebih kompleks dan mendalam.

Untuk materi tata bahasa dimulai dengan pembelajaran tentang isim isyarah dan isim dhomir yang kemudian diperluas pembahasannya pada tingkat kelas lanjutnya. Kemudian tema yang banyak dibahas selanjutnya adalah tentang mubtada + khobar, fi'il mudhori, fi'il amar, fi'il madhi.Tema-tema ini juga kemudian diperluas setelahnya dengan pembahasan yang lebih komprehensif seperti mempelajari jumlah ismiyah dan jumlah fi'liyah dengan menggunakan berbagai bentuk kata. Pendalaman tentang fi'il-fi'il tersebut juga diperluas dengan mempelajari tashrif-tashrifnya beserta penggunaannya dalam kalimat. Adapun tema-tema lain yang dipelajari adalah harfu jar, al-istifham, al-arqam, fa'il, maf'ul, as'ilah 'an as-sa'ah, ism tafdhil, isim kaana dan isim maushuul. Semua tema-tema tersebut telah disusun dengan siklus yang baik yakni dengan mendahulukan pengajaran tema yang mudah ke tema yang lebih sulit dan ke tema yang paling sulit. Namun untuk menghindari pengulangan dengan materi yang sama sangat bergantung pada pengembangan materi tersebut dalam bentuk buku teks.

Namun jika kita kaitkan dengan pendapat An-Naqoh tentang materi-materi tata bahasa dasar yang harus diajarkan dalam pembelajaran bahasa Arab, maka materi-materi tata bahasa di kelas I MI hingga kelas XIIMA tersebut masih belum lengkap dimana masih terdapat beberapa tema yang belum diajarkan seperti annawa akhwatuha, hal, istitsna, tamyiiz, huruful 'athfi dan asma' khomsah.

\section{KESIMPULAN}

Kompetensi Dasar (KD) mata pelajaran bahasa Arab dalam kurikulum 2013 disajikan berdasarkan tiga ranah taksonomi tujuan pendidikan, yaitu ranah sikap (sikap spritual dan sosial), ranah pengetahuan, dan ranah keterampilan. Ranah sikap menekankan pada nilai yang ingin dicapai melalui 
pembelajaran bahasa Arab dan tidak berhubungan secara langsung dengan tujuan pembelajaran bahasa yang terkait dengan empat keterampilan berbahasa. Sedangkan ranah pengetahuan dan keterampilan menekankan pada penguasaan empat kemahiran berbahasa Arab dan dua komponen bahasa.

Secara umum, sequence Kompetensi Dasar (KD) dalam mata pelajaran bahasa Arab mulai dari kelas I MI hingga kelas XII MI disajikan mulai dari kompetensi dengan bentuk yang sederhana menuju bentuk kegiatan yang lebih kompleks. Namun, beberapa kelemahan yang ditemukan adalah terdapat penurunan kompetensi kemahiran menyimak pada jenjang Madrasah Aliyah (MA) dan tidak dicantumkan fokus pembelajaran membaca dengan suara keras/nyaring pada awal-awal jenjang pendidikan (MI-MTs). Sedangkan untuk materi pelajaran dan materi tata bahasa digunakan spiral sequencing, dimana terdapat beberapa pengulangan tema pada kelas selanjutnya. Beberapa pengulangan tersebut merupakan penguatan dan pendalaman materi sebelumnya. Namun, terdapat pula penyajian materi yang sama dengan materi pada kelas sebelumnya. 


\section{DAFTAR PUSTAKA}

An-Naqoh, M. K. (1985). Ta'limullughah al-'arabiyah. Mekah: Jami'ah Ummul Qura.

Azizah, F. L. (2013). Kajian terhadap SCope, Balance dan Desain Kurikulum Bahasa Arab Tingkat Menengah Perspektif I.S.P Nation dan John Macalister. UIN Sunan Kalijaga Yogyakarta.

Kementerian Agama Republik Indonesia. 2014. Buku Guru Bahasa Arab Pendekatan Saintifik Kurikulum 2013 Madrasah Intidaiyah Kelas I. Jakarta: Kementerian Agama Republik Indonesia.

Kementerian Agama Republik Indonesia. 2014. Buku Guru Bahasa Arab Pendekatan Saintifik Kurikulum 2013 Madrasah Intidaiyah Kelas IV. Jakarta: Kementerian Agama Republik Indonesia.

Kementerian Agama Republik Indonesia. 2014. Buku Siswa Bahasa Arab Pendekatan Saintifik Kurikulum 2013 Madrasah Intidaiyah Kelas I. Jakarta: Kementerian Agama Republik Indonesia.

Kementerian Agama Republik Indonesia. 2014. Buku Siswa Bahasa Arab Pendekatan Saintifik Kurikulum 2013 Madrasah Intidaiyah Kelas IV. Jakarta: Kementerian Agama Republik Indonesia.

Kementerian Agama Republik Indonesia. 2014. Durusul Lughah Al-'Arabiyah: Buku Guru Bahasa Arab Pendekatan Saintifik Kurikulum 2013 Madrasah Tsanawiyah Kelas VII. Jakarta: Kementerian Agama Republik Indonesia.

Kementerian Agama Republik Indonesia. 2014. Durusul Lughah Al-'Arabiyah: Buku SIswa Bahasa Arab Pendekatan Saintifik Kurikulum 2013 Madrasah Tsanawiyah Kelas VII. Jakarta: Kementerian Agama Republik Indonesia.

Keputusan Menteri Agama Republik Indonesia Nomor 117 tahun 2014 tentang Implementasi Kurikulum 2013 di Madrasah.

Keputusan Menteri Agama Republik Indonesia Nomor 207 tahun 2014 tentang Kurikulum Madrasah.

Lampiran Peraturan Agama Republik Indonesia Nomor 000912 tahun 2013 tentang kurikulum madrasah 2013 mata pealajaran Pendidikan Agama Islam dan Bahasa Arab.

Lampirat Surat Keputusan DIrektur Jenderal Pendidikan Islam Nomor: 2676 tahun 2013 tentang Kurikulum 2013 Mata Pelajaran Pendidikan Agama Islam dan bahasa Arab di Madrasah. 
Maula, I. (2012). Model Kurikulum Bahasa Arab Tingkat Menengah (Studi Analisis terhadap Sequence dalam Kurikulum sesuai PERMENAG Nomor 2 Tahun 2008). UIN SUnan Kalijaga Yogyakarta.

Nasution, S. (2006). Asas-asas Kurikulum. Jakarta: Bumi Aksara.

Pohan, R. (2007). Metodologi Penelitian Pendidikan. Yogyakarta: Ar-Rijal Institute.

Richards, J. C. (2001). Curriculum Development in Language Teaching. New York: Cambridge University Press.

Silabus Pembelajaran mata Pelajaran Bahasa Arab keals I Madrasah Ibtidaiyah.

Silabus Pembelajaran mata Pelajaran Bahasa Arab keals II Madrasah Ibtidaiyah.

Silabus Pembelajaran mata Pelajaran Bahasa Arab keals IV Madrasah Ibtidaiyah.

Silabus Pembelajaran mata Pelajaran Bahasa Arab keals V Madrasah Ibtidaiyah.

Silabus Pembelajaran mata Pelajaran Bahasa Arab keals VII Madrasah Tsanawiyah.

Silabus Pembelajaran mata Pelajaran Bahasa Arab keals VIII Madrasah Tsanawiyah.

Silabus Pembelajaran mata Pelajaran Bahasa Arab keals X Madrasah Aliyah.

Silabus Pembelajaran mata Pelajaran Bahasa Arab keals XI Madrasah Aliyah.

Surat Keputusan Direktur Jenderal Pendidikan Islam Nomor: 2676 Tahun 2013 tentang Kurikulum 2013 Mata Pelajaran Pendidikan Agama Islam dan Bahasa Arab di Madrasah.

Sutopo, H. dan W. S. (1986). Pembinaan dan Pengembangan Kurikulum: sebagai substansi problem administrasi pendidikan. Bina Aksara. 